\title{
Analysis of the Growth Mindset Levels of the Pre-Service Teachers According to Some Variables
}

\author{
Sema Irem Orhan ${ }^{1}$, Abdullah Aydin ${ }^{2, *}$ \\ ${ }^{1}$ Kastamonu University, Kastamonu, 37150, Turkey \\ ${ }^{2}$ Department of Mathematics and Science Education, Faculty of Education, Kastamonu University, 37200, Kastamonu, Turkey
}

Received September 12, 2021; Revised October 14, 2021; Accepted November 21, 2021

\begin{abstract}
Cite This Paper in the following Citation Styles
(a): [1] Sema Irem Orhan, Abdullah Aydin, "Analysis of the Growth Mindset Levels of the Pre-Service Teachers According to Some Variables," Universal Journal of Educational Research, Vol. 9, No. 12, pp. 1898 - 1904, 2021. DOI: 10.13189/ujer.2021.091202.
\end{abstract}

(b): Sema Irem Orhan, Abdullah Aydin (2021). Analysis of the Growth Mindset Levels of the Pre-Service Teachers According to Some Variables. Universal Journal of Educational Research, 9(12), 1898 - 1904. DOI: 10.13189/ujer.2021.091202.

Copyright $\odot 2021$ by authors, all rights reserved. Authors agree that this article remains permanently open access under the terms of the Creative Commons Attribution License 4.0 International License

\begin{abstract}
The aim this study is to investigate the growth mindset levels of the pre-service teachers according to gender, the program they studied and the grade level, and to reveal descriptive inferences in this direction. For this purpose, the research was carried out with 534 pre-service teachers studying in 10 different teaching programs. Data on the current growth mindset levels of the pre-service teachers were obtained with the Mindset Scale (MS). As a result of this study, it was observed that the growth mindset levels of the pre-service teachers did not change statistically according to gender, the program they studied and the grade level. However, when looking at the mean rank, it was determined that female's growth mindset levels were higher than male's. According to the program they were studying, it was seen that the highest growth mindset level was among the pre-service teachers studying in department of art education. According to the grade level, it was determined that the highest growth mindset level was among the pre-service teachers studying in the first grade.
\end{abstract}

Keywords Growth Mindset, Pre-Service Teacher, Gender, Teaching Program, Grade Level

\section{Introduction}

The personal views of individuals about the nature of intelligence are defined as the theory of implicit intelligence [1]. In this context, it is possible to talk about two self-theories. These are the developmental self-theory and the entity self-theory. According to developmental self-theory, intelligence and abilities are traits that can be developed over time $[2,3,4]$. Contrary to this view, the entity self-theory argues that intelligence and abilities are innate limited traits and therefore cannot be developed [5, 6].

There are two types of mindsets such as growth mindset and fixed mindset. The theories are also called as mindset. [2] claims that when someone goes into a mindset, he/she goes into a new and different world. The students who have fixed mindset believe that achievement has engagement between being smart or talented. Having bad marks, making mistakes, getting rejected and losing a competition are terrible agents and they believe that they are not smart or talented. While, the students who have fixed mindset think that only talent provides achievement, effort is not required, the students who have growth mindset believe that everyone may become smarter. Provided with time, practice and experience, they could improve their intelligence [7]. According to this; individuals who believe in the entity self-theory, which argues that intelligence and abilities are innate and cannot be developed, are defined as individuals with a fixed mindset, while individuals who believe in the developmental self-theory, which argues that talents and intelligence can be developed with effort, are defined as 
individuals with a growth mindset $[2,8]$. For instance, some people who have fixed mindset accept that human beings are born with intelligence and everyone is born with stable capacity and it is inevitable to change this case, while some people who have growth mindset think personal trait is changeable and person capacity and intelligence are always changeable and malleable [7].

According to [2] individuals with a growth mindset do not lose their courage when they encounter failure in any aspect in their daily lives and describe their failures as a part of the learning process. Individuals with a fixed mindset are often disappointed in the face of failure and can easily give up trying to learn [9]. Therefore, it is reported that individuals with a growth mindset are more successful than individuals with a fixed mindset because they are more resistant to difficulties [2].

Some studies conducted within this framework show that the beliefs, behaviors and feelings of the people in the social environment, as well as one's own beliefs, are also effective for the person [10]. [11] reports that teachers' beliefs about their students' abilities and success in the lesson are communicated to their students through their words and actions. Similarly, [12] found that the biggest influence on a student's academic achievement is the classroom teacher. In this context, some research results conducted in the field of education provide evidence that the mindset of teachers is effective on the mindset of students [13-16]. [17] determined that the mindset of the teachers affects the classroom performance of the students as well as the mindset of the students. On the other hand, [18] reported that the mindset of teachers has strong effects on the teaching approaches they adopt and their classroom behaviors.

It is a known fact that teachers' teaching practices and interactions with students are affected by their motivations and previous teaching experiences [19]. Considering all research results in the literature and the fact that the education process takes place in mutual interaction environments, it can be predicted how important the mindset of teachers is in maintaining the relevant education process in a qualified way. In addition, studies provide evidence that the growth mindset increases teachers' expertise in their professional development efforts [20] and greatly affects their interactions with students [21].

Because of the literature review, it has been determined that the studies in the national literature on the growth mindset, which is very popular in the international literature, are quite limited. It has been determined that the studies on teachers and pre-service teachers are not sufficient. In the research carried out, it focuses on determining the growth mindset of pre-service teachers who will be the teachers of the future, and it is thought that the research will contribute to both national and international literature in this context.

\subsection{The Aim of the Study}

The aim this study is to investigate the growth mindset levels of the pre-service teachers according to gender, the program they studied and the grade level, and to reveal descriptive inferences in this direction. Within the scope of this study, the following research questions were tried to be responded:

The growth mindset levels of the pre-service teachers,

1. Does it show a significant difference according to the gender variable?

2. Does it show a significant difference according to the teaching program?

3. Does it show a significant difference according to the grade level?

\section{Methods}

\subsection{Model of the Study}

This research is a descriptive study in which the screening model is used, based on the quantitative research approach. In the screening model, a pre-existing or ongoing situation is described transparently and the situation that is the subject of the research is defined within the framework of its current conditions and as it is [22].

\subsection{Participants}

The study was conducted at 10 different teaching programs, which are art, classroom, computer and instructional technologies, guidance and psychological counseling, mathematics, music, pre-school, science, social sciences and Turkish in faculty of education of a university in Turkey in the 2020-2021 academic year. The participants of the study are 534 pre-service teachers studying in these programs. Percentage and frequency distribution of pre-service teachers according to gender and program variables are presented in Table 1. 
Table 1. Distribution of pre-service teachers according to gender and teaching program

\begin{tabular}{|c|c|c|c|c|c|c|}
\hline \multirow{3}{*}{$\begin{array}{l}\text { Teaching } \\
\text { program }\end{array}$} & \multicolumn{4}{|c|}{ Gender } & \multirow{2}{*}{\multicolumn{2}{|c|}{ Total }} \\
\hline & \multicolumn{2}{|c|}{ Female } & \multicolumn{2}{|c|}{ Male } & & \\
\hline & $\mathrm{f}$ & $\%$ & $\mathrm{f}$ & $\%$ & $\mathrm{f}$ & $\%$ \\
\hline Art & 12 & 2.25 & 3 & 0.56 & 15 & 2.81 \\
\hline Classroom & 62 & 11.61 & 18 & 3.37 & 80 & 14.98 \\
\hline Computer and Instructional Technologies & 2 & 0.37 & 9 & 1.68 & 11 & 2.05 \\
\hline Guidance and Psychological Counseling & 80 & 14.98 & 30 & 5.62 & 110 & 20.60 \\
\hline Mathematics & 51 & 9.55 & 12 & 2.25 & 63 & 11.80 \\
\hline Music & 6 & 1.12 & 3 & 0.56 & 9 & 1.68 \\
\hline Pre-School & 92 & 17.23 & 14 & 2.62 & 106 & 19.85 \\
\hline Science & 25 & 4.68 & 5 & 0.94 & 30 & 5.62 \\
\hline Social Sciences & 33 & 6.18 & 11 & 2.06 & 44 & 8.24 \\
\hline Turkish & 52 & 9.74 & 14 & 2.63 & 66 & 12.37 \\
\hline Total & 415 & 77.71 & 119 & 22.29 & 534 & 100 \\
\hline
\end{tabular}

Table 2. Distribution of pre-service teachers according to gender and grade levels

\begin{tabular}{|c|c|c|c|c|c|c|}
\hline \multirow{3}{*}{ Grade level } & \multicolumn{4}{|c|}{ Gender } & \multirow{2}{*}{\multicolumn{2}{|c|}{ Total }} \\
\hline & \multicolumn{2}{|c|}{ Female } & \multicolumn{2}{|c|}{ Male } & & \\
\hline & $\mathrm{f}$ & $\%$ & $\mathrm{f}$ & $\%$ & $\mathrm{f}$ & $\%$ \\
\hline First grade & 98 & 18.35 & 25 & 4.68 & 123 & 23.03 \\
\hline Second grade & 95 & 17.79 & 20 & 3.75 & 115 & 21.54 \\
\hline Third grade & 120 & 22.47 & 26 & 4.87 & 146 & 27.34 \\
\hline Fourth grade & 102 & 19.10 & 48 & 8.99 & 150 & 28.09 \\
\hline Total & 415 & 77.71 & 119 & 22.29 & 534 & 100 \\
\hline
\end{tabular}

When Table 1 is examined, the highest rate of participation in the study was provided by the guidance and psychological counseling program (20.60\%), and the lowest participation was by the music teaching program (1.68\%). $77.71 \%$ of the participants are female and $22.29 \%$ are male. The frequency and percentage distribution of pre-service teachers according to their gender and grade levels are given in Table 2.

As seen in Table 2, the most participants were from the fourth grades $(28.09 \%)$, and the least from the second grades $(21.54 \%)$.

\subsection{Data Collection Tool}

In this study, quantitative research design was used. In order to collect data on the mindset levels of pre-service teachers, the Mindset Scale (MS) was used. This scale was developed by [23] and it consists of 8 items in a five-point Likert type (1=Strongly disagree, $2=$ Disagree, $3=$ Neutral, 4=Agree, 5=Strongly agree). The higher the score obtained from the scale, the more growth mindset the individual has, the lower it is, the more fixed mindset it shows.

The scale, which was originally in English, was adapted into Turkish and used in the research. The scale was translated into Turkish by two instructors and a translator, whose native languages are fluent in Turkish and English, independently of each other. The Turkish version of the scale was translated back into English by a native English and fluent translator and compared with the original scale. A report has been prepared for differences between translations, cultural adaptation and appropriate word selection. The Cronbach Alpha value of the English version of the scale was determined as 0.90 , validity and reliability studies were conducted and the Cronbach Alpha internal consistency coefficient was found to be 0.85 and was used in the research with the necessary permission.

\subsection{Application Process}

The scale application was prepared through Office 365 Forms due to the COVID-19 pandemic and was conducted online between, 28 May-25 June 2021 on a voluntary basis and after obtaining the necessary permissions, for pre-service teachers studying at faculty of education of a university in Turkey in the spring semester of 2020-2021 academic year. 


\subsection{Analysis of the Data}

Descriptive statistics (frequency-percentage) and statistical analysis methods were used in the analysis of the obtained data. In order to use parametric hypothesis tests, the data should be spaced or proportional, fit normal distribution, and group variances should be equal [24]. For this reason, the data were analyzed with the SPSS package program in order to determine the appropriate tests for the analysis of the research data. In this direction, to determine whether the data obtained from the MS used in the study showed a normal distribution, Kolmogorov-Smirnov [25] normality test was used for the sample with 35 or more observations and Shapiro-Wilk [26] normality test for those below 35 . The results of the analysis of data are provided in Table 3 .

Table 3. Results of the normality test

\begin{tabular}{ccccc}
\hline Teaching Program & $\mathbf{N}$ & $\overline{\mathbf{X}}$ & SD & $\boldsymbol{p}$ \\
\hline Art & 15 & 86.667 & 3.288 & 0.106 \\
\hline Classroom & 80 & 81.406 & 1.622 & $0.033^{*}$ \\
\hline $\begin{array}{c}\text { Computer and Instructional } \\
\text { Technologies }\end{array}$ & 11 & 81.136 & 3.394 & 0.520 \\
\hline $\begin{array}{c}\text { Guidance and } \\
\text { Psychological Counseling }\end{array}$ & 110 & 79.364 & 1.415 & $0.000^{*}$ \\
\hline Mathematics & 63 & 82.222 & 1.684 & 0.075 \\
\hline Music & 9 & 82.778 & 5.060 & 0.344 \\
\hline Pre-School & 106 & 80.613 & 1.655 & $0.000^{*}$ \\
\hline Science & 30 & 82.333 & 2.653 & $0.023 *$ \\
\hline Social Sciences & 44 & 81.705 & 2.059 & $0.010^{*}$ \\
\hline Turkish & 66 & 84.546 & 1.676 & $0.002^{*}$ \\
\hline$p<.05 \quad 00$ & & & \\
\hline & & & &
\end{tabular}

When Table 3 is examined, the data sets obtained from computer and instructional technologies, mathematics, music and art teaching programs show a normal distribution $(p>.05)$, while the data sets obtained from science, pre-school, guidance and psychological counseling, classroom, social sciences and Turkish teaching programs science did not show a normal distribution $(p<.05)$. The data regarding the homogeneity of the group variances of the data obtained within the scope of the research are presented in Table 4.

Table 4. Results of the homogeneity of variances

\begin{tabular}{ccccc}
\hline Scale & Levene & df1 & df2 & $\boldsymbol{p}$ \\
\hline MS & 1.373 & 9 & 524 & 0.197 \\
\hline
\end{tabular}

According to Table 4, it was determined that the variances of the data obtained with the MS were homogeneous. When Table 3 and Table 4 are evaluated together, it was deemed appropriate to use the Mann-Whitney $\mathrm{U}$ test and Kruskal-Wallis $\mathrm{H}$ test, which are non-parametric tests, in the analysis of the data obtained with the MS.

\section{Results}

In this section, the findings from the MS are arranged and interpreted based on each research question

\subsection{Findings Concerning the First Problem of the Study}

In line with the first problem, the data obtained from the pre-service teachers with the MS were subjected to the Mann-Whitney U test, to determine whether the mindset levels of pre-service teachers differ significantly in terms of gender. The results of the analysis of data are provided in Table 5.

Table 5. Results of the Mann-Whitney U test in terms of gender

\begin{tabular}{|c|c|c|c|c|c|}
\hline Gender & $\mathbf{N}$ & $\begin{array}{l}\text { Mean } \\
\text { Rank }\end{array}$ & $\begin{array}{l}\text { Sum of } \\
\text { Ranks }\end{array}$ & $\mathbf{U}$ & $p$ \\
\hline Female & 415 & 271.02 & 112472.00 & \multirow{2}{*}{23233.00} & \multirow{2}{*}{0.324} \\
\hline Male & 119 & 255.24 & 30373.00 & & \\
\hline
\end{tabular}

According to Table 5, it is seen that there is no statistically significant difference between pre-service teachers in terms of MS scores according to the gender variable $(\mathrm{U}=23233.00 ; p>.05)$. However, when the mean rank is taken into account, it was determined that female's the growth mindset levels are higher than male's.

\subsection{Findings Concerning the Second Problem of the Study}

In line with the second problem, it was found appropriate to use the Kruskal-Wallis $\mathrm{H}$ test, one of the non-parametric tests, to determine whether the mindset levels of pre-service teachers differ significantly in terms of the teaching program studied. The results of the analysis of data are provided in Table 6.

Table 6. Kruskal-Wallis $\mathrm{H}$ test results in terms of the teaching program studied

\begin{tabular}{cccccc}
\hline $\begin{array}{c}\text { Teaching } \\
\text { Program }\end{array}$ & N & $\begin{array}{c}\text { Mean } \\
\text { Rank }\end{array}$ & df & $\boldsymbol{X}^{2}$ & $\boldsymbol{p}$ \\
\hline Art & 15 & 319.53 \\
\hline Classroom & 80 & 263.06 & & & \\
\hline $\begin{array}{c}\text { Computer and } \\
\text { Instructional } \\
\text { Technologies }\end{array}$ & 11 & 246.14 & & & \\
\hline $\begin{array}{c}\text { Guidance and } \\
\text { Psychological } \\
\text { Counseling }\end{array}$ & 110 & 243.76 & & \\
\hline Mathematics & 63 & 269.99 \\
\hline Music & 9 & 280.39 \\
\hline Pre-School & 106 & 266.34 \\
\hline Science & 30 & 276.87 \\
\hline Social Sciences & 44 & 265.27 \\
\hline Turkish & 66 & 299.14 & & \\
\hline
\end{tabular}

According to Table 6, there was no statistically 
significant difference $(p>.05)$ between the teaching program and the mindset level that the pre-service teachers have. However, when the mean rank is taken into account, it was determined that while the level of the growth mindset of the pre-service teachers studying in the art teaching program is the highest, the level of the pre-service teachers studying in the guidance and psychological counseling teaching program is the lowest.

\subsection{Findings Concerning the Third Problem of the Study}

In line with the second problem, it was found appropriate to use the Kruskal-Wallis $\mathrm{H}$ test, one of the non-parametric tests, to determine whether the mindset levels of pre-service teachers differ significantly in terms of the grade level. The data obtained are presented in Table 7.

Table 7. Kruskal-Wallis $\mathrm{H}$ test results in terms of the grade level

\begin{tabular}{cccccc}
\hline $\begin{array}{c}\text { Grade } \\
\text { Level }\end{array}$ & N & $\begin{array}{c}\text { Mean } \\
\text { Rank }\end{array}$ & df & $\boldsymbol{X}^{2}$ & $\boldsymbol{p}$ \\
\cline { 1 - 3 } First grade & 123 & 286.21 & & & \\
\cline { 1 - 3 } Second grade & 115 & 271.82 & & 4.239 & 0.237 \\
\cline { 1 - 3 } Third grade & 146 & 266.88 & & & \\
\cline { 1 - 3 } Fourth grade & 150 & 248.43 & & & \\
\hline
\end{tabular}

According to Table 7, there was no statistically significant difference $(p>.05)$ between the grade level and the mindset level that the pre-service teachers have. However, when the mean rank is taken into account, it was determined that while the level of the growth mindset of the pre-service teachers studying in the first grade is the highest; the level of the pre-service teachers studying in fourth grade is the lowest.

\section{Conclusions and Discussion}

According to the findings obtained by the analysis of the data obtained from the research carried out to determine the mindset levels of the pre-service teachers, no statistically significant difference was found between the genders of the pre-service teachers and the growth mindset levels they have. When the literature is examined, it is seen that there are limited studies on the growth mindset and its relationship with gender, although [27] similarly, in their study on young Icelandic adults, found that the growth mindset did not differ according to gender.

As a result of his research, [28] found that women tended to develop a more fixed mindset in the face of difficult math problems than men and that women benefited more from growth mindset interventions. [29] in their study, supporting [28] research, concluded that women benefit more from growth mindset interventions than men. [30] conducted a study with 226 Swiss high school teachers and determined that fixed mindset might be more common among numeracy teachers, but in this study, it was determined that the mindset levels of pre-service teachers did not show a statistically significant difference according to the teaching program they studied.

In this study, no significant difference was found between the mindset levels of pre-service teachers and the grade level they studied. Although there is no research in the literature that deals with the mindset of pre-service teachers in terms of grade levels, [30] found that teachers tend to display more fixed mindset in the first and last years of their careers than in other periods.

Although no statistically significant difference could be detected within the framework of grade levels in this study, when the mean rank was examined, it was determined that the mindset of pre-service teachers decreased from the first grade to the fourth grade. This result shows that pre-service teachers started their education with a higher level of growth mindset, but their level of growth mindset decreased over time. It is thought that this may be due to the fact that pre-service teachers have not been able to deal with the failures and difficulties they encounter during their education process.

The literature provides evidence that the mindset of teachers has important effects on both the aspects of their teaching careers and the mindset of their students. In this context, it is seen that teachers play an important role in raising individuals with a growth mindset in society. Therefore, it is thought that it is very important for pre-service teachers who will be teachers in the future to develop a mindset in their education processes and to receive training on the integration of this mindset into classroom environments. For this reason, it is thought that integrating the trainings to develop a growth mindset into existing teacher training programs and informing those who have started their teaching career with in-service trainings on the subject will contribute to raising qualified individuals who are suitable for today's society needs. Recent studies in the literature [31,32] also provide evidence of the importance of developing teachers' growth mindset levels.

\section{Compliance with Ethical Standards}

\section{Ethical Statement of the Study}

As authors of the research, we declare that the study has no unethical problem and we observed research and publication ethics. Ethical principles and rules were followed during the planning, data collection, analysis and reporting of the research. Ethical compliance approval was obtained for this research in accordance with the decision of Kastamonu University Social and Human Sciences Research and Publication Ethics Committee 
dated 25.03.2021 and numbered 01/09.

\section{Researchers' Contribution Rate}

The study was conducted and reported with equal collaboration of the researchers.

\section{Conflict of Interest}

The authors declare that they have no conflict of interest.

A part of the research was presented orally in the 3rd International Conference on Science, Mathematics, Entrepreneurship and Technology Education (Online) 30 September-3 October 2021, Uludağ University, Bursa, Turkey.

\section{REFERENCES}

[1] Sternberg, R. J., Conway, B. E., Ketron, J. L., \& Bernstein M. (1981). People's conceptions of intelligence. Journal of Personality and Social Psychology, 41(1), 37-55. https://doi.org/10.1037/0022-3514.41.1.37

[2] Dweck, C. S. (2006). Mindset: How we can learn to fulfil our potential. New York, NY: Random.

[3] Orosz, G., Péter-Szarka, S., Bőthe, B., Tóth-Király, I., \& Berger, R. (2017). How not to do a mindset intervention: Learning from a mindset intervention among students with good grades. Frontiers in Psychology, 8, Article 311, https://doi.org 10.3389/fpsyg.2017.00311

[4] Keenan, M. (2018). The impact of growth mindset on student self-efficacy. Degree of Master of Education, Goucher College, Baltimore, Maryland, 2018.

[5] Dweck, C. S., \& Leggett, E. L. (1988). A social-cognitive approach to motivation and personality. Psychological Review, 95(2), 256-273. https://doi.org/10.1037/0033-295 X.95.2.256

[6] Walters, S. (2014). Growth mindsets: A literature review. Temescal Associates. http://www.temescalassoc.com/db/ el/files/2015/02/Growth-Mindsets-Lit-Review.pdf.

[7] Delibalta, M. A. (2020). The relationship between mindset and causal attribution in the EFL context. Master's thesis, the Institute of Social Sciences, Çăg University, Mersin, Turkey.

[8] Dweck, C. S. (2015). Carol Dweck revisits the growth mindset. Education Week, 35(5), 20-24.

[9] Miller, D. L. (2013). Got it wrong? Think again and again. Phi Delta Kappan, 94(5), 50-52. https://doi.org/10.1177/003172171309400511

[10] Christakis, N. A., \& Fowler, J. H. (2013). Social contagion theory: Examining dynamic social networks and human behavior. Statistics in Medicine, 32, 556-577. https://doi.org/10.1002/sim.5408
[11] Dweck, C. S. (2010). Mind-sets and equitable education. Principal Leadership, 10(5), 26-29.

[12] Fullan, M. (2014). The principal: Three keys to maximizing impact. San Francisco, CA: Wiley, 2014.

[13] Bostwick, K. C., Collie, R. J., Martin, A. J., \& Durksen, T. L. (2020). Teacher, classroom, and student growth orientation in mathematics: A multilevel examination of growth goals, growth mindset, engagement, and achievement. Teaching and Teacher Education, 94, 103100. https://doi.org/10.1016/j.tate.2020.103100

[14] Muenks, K., Yan, V. X., \& Telang, N. K. (2021). Who is part of the "mindset context"? the unique roles of perceived professor and peer mindsets in undergraduate engineering students' motivation and belonging. Frontiers in Education, 6, 633570. https://doi.org/10.3389/feduc.2021.633570

[15] Sun, K. L. (2018). Brief report: the role of mathematics teaching in fostering student growth mindset. Journal for Research in Mathematics Education, 49(3), 330-335. https://doi.org/10.5951/jresematheduc.49.3.0330

[16] Woodcock, S., \& Jiang, H. (2018). A cross-national comparison of attributional patterns toward students with and without learning disabilities. Journal of Learning Disabilities, 51(2), 3-17.

[17] Shim, S. S., Cho, Y., \& Cassady, J. (2013). Goal structures: The role of teachers' achievement goals and theories of intelligence. The Journal of Experimental Education, 81(1), 84-104. https://doi.org/10.1080/00220973.2011.635168

[18] Swann, W. B., \& Snyder, M. (1980). On translating beliefs into action: Theories of ability and their application in an instructional setting. Journal of Personality and Social Psychology, 38(6), 879-888. https://doi.org/10.1037/00223514.38.6.879

[19] Trigwell, K. (2012). Relations between teachers' emotions in teaching and their approaches to teaching in higher education. Instructional Science, 40, 607-621. https://doi.org/10.1007/s11251-011-9192-3

[20] Bartz, D. E. (2016). What is your "mindset"? And do you have "Grit"?, Leadership matters, Springfield, IL: IASA

[21] Rissanen, I., Kuusisto, E., Tuominen, M., \& Tirri, K. (2019). In search of a growth mindset pedagogy: A case study of one teacher's classroom practices in a Finnish elementary school. Teaching and Teacher Education, 77, 204-213.

[22] Karasar, N. (2012). Bilimsel araştırma yöntemi [Scientific research method]. Nobel Publishing, Ankara, Turkey.

[23] De Castella, K., \& Byrne, D. (2015). My intelligence may be more malleable than yours: The revised implicit theories of intelligence (self-theory) scale is a better predictor of achievement, motivation, and student disengagement. European Journal of Psychology of Education, 30, 245-267. https://doi.org/10.1007/s10212-015-0244-y

[24] Kalaycı, S. (2006). SPSS uygulamalı çok değișkenli istatistik teknikleri [SPSS applied multivariate statistical techniques]. Asil Publishing, Ankara, Turkey.

[25] McKillup, S. (2012). Statistics explained: An introductory guide for life scientists (2nd ed.). United States: Cambridge University Press. 
[26] Shapiro, S. S., \& Wilk, M. B. (1965). An analysis of variance test for normality (complete samples). Biometrika, 52(3/4), 591-611.

[27] Sigmundsson, H., Haga, M., \& Hermundsdottir, F. (2020). Passion, grit and mindset in young adults: Exploring the relationship and gender differences. New Ideas in Psychology, 59, 100795. https://doi.org/10.1016/j.newidea psych.2020.100795

[28] Dweck, C. S. (2007). Is math a gift? Beliefs that put females at risk. (S. J. C. \& W. M. Williams (ed.)). Washington: American Psychological Association Press.

[29] Degol, J. L., Wang, M. T., Zhang, Y., \& Allerton, J. (2018). Do growth mindsets in math benefit females? Identifying pathways between gender, mindset, and motivation. Journal of Youth and Adolescence, 47, 976-990. https://doi.org/10.1007/s10964-017-0739-8
[30] Jonsson, A. C., Beach, D., Korp, H., \& Erlandson, P. (2012). Teachers' implicit theories of intelligence: Influences from different disciplines and scientific theories. European Journal of Teacher Education, 35(4), 387-400. https://doi.org/10.1080/02619768.2012.662636

[31] Keesey, S., Schaefer, A., Loy, M., \& Allen, C. J. (2018). Developing growth mindset and GRIT in preservice teachers. Kentucky Teacher Education Journal: The Journal of the Teacher Education Division of the Kentucky Council for Exceptional Children, 5(1), Article 3.

[32] Stephens, J. M., Rubie-Davies, C., \& Peterson, E. R. (2021). Do preservice teacher education candidates' implicit biases of ethnic differences and mindset toward academic ability change over time? Learning and Instruction, available online 31 March 2021, 101480. https://doi.org/10.1016/j.le arninstruc.2021.101480 